\title{
Attempts for Developing Novel Sugar-Based and Sugar-Free Sea Buckthorn Marmalades
}

\author{
Oana-Viorela Nistor, Carmen Alina Bolea, Doina-Georgeta Andronoiu, Mihaela Cotârleț and Nicoleta Stănciuc * $\mathbb{D}$
}

check for

updates

Citation: Nistor, O.-V.; Bolea, C.A.; Andronoiu, D.-G.; Cotârleț, M.; Stănciuc, N. Attempts for Developing Novel Sugar-Based and Sugar-Free Sea Buckthorn Marmalades. Molecules 2021, 26, 3073. https://doi.org/ $10.3390 /$ molecules 26113073

Academic Editors: Maria C.

Giannakourou and Vassilia

J. Sinanoglou

Received: 29 April 2021

Accepted: 19 May 2021

Published: 21 May 2021

Publisher's Note: MDPI stays neutral with regard to jurisdictional claims in published maps and institutional affiliations.

Copyright: (c) 2021 by the authors. Licensee MDPI, Basel, Switzerland. This article is an open access article distributed under the terms and conditions of the Creative Commons Attribution (CC BY) license (https:// creativecommons.org/licenses/by/ $4.0 /)$.
Faculty of Food Science and Engineering, Dunărea de Jos University of Galati, 800008 Galati, Romania; Oana.Nistor@ugal.ro (O.-V.N.); Carmen.Bolea@ugal.ro (C.A.B.); Georgeta.Andronoiu@ugal.ro (D.-G.A.); Mihaela.Cotarlet@ugal.ro (M.C.)

* Correspondence: nsava@ugal.ro; Tel.: +40-0336-130-183

\begin{abstract}
Sea buckthorn (Hippophae rhamnoides L.) is recognized as a valuable source of vitamin C and antioxidants, frequently used as nutraceuticals and cosmeceuticals. In the present study, attempts are made to produce and characterize a novel type of marmalade using sea buckthorn berries processed at $102{ }^{\circ} \mathrm{C}$ into marmalade in two combinations, with whole cane or stevia sugar. Changes in the phytochemical profile, antioxidant activity, color, shelf-life, texture, microbiological, and sensorial characteristics were determined. The total carotenoids content in the marmalades were significantly different, with values of $0.91 \pm 0.03 \mathrm{mg} / \mathrm{g}$ dry weight $(\mathrm{DW})$ in the sample with whole sugar cane $\left(C_{z}\right)$ and $2.69 \pm 0.14 \mathrm{mg} / \mathrm{g}$ DW in the sample with Stevia sugar $\left(\mathrm{C}_{\mathrm{s}}\right)$. Significant values of polyphenols were found, of $59.41 \pm 1.13 \mathrm{mg} \mathrm{GAE} / \mathrm{g} \mathrm{DW}$ in $\mathrm{C}_{\mathrm{z}}$ and $72.44 \pm 2.31 \mathrm{mg} \mathrm{GAE} / \mathrm{g} \mathrm{DW}$ in $\mathrm{C}_{\mathrm{s}}$, leading to an antioxidant activity of $45.12 \pm 0.001 \mu \mathrm{Mol}$ Trolox/g DW and $118.07 \pm 0.01 \mu \mathrm{Mol}$ Trolox $/ \mathrm{g}$ DW, respectively. Accelerated storage study showed a decrease in all the phytochemicals, however no significant changes were found in antioxidant activity. Values of $<100 \mathrm{CFU} / \mathrm{g}$ for yeasts and molds and $<5 \mathrm{CFU} / \mathrm{g}$ for Enterobacteriaceae after 21 days of storage at the room temperature of the marmalades were determined. The sensorial and color results were more than acceptable. Overall, the results highlighted the potential of using sea buckthorn as a potential rich source of bioactive compounds to be used in the sugar-based products manufacturing.
\end{abstract}

Keywords: berry fruit; stevia; bioactive compounds; shelf-life; antioxidant activity

\section{Introduction}

Sea buckthorn (Hippophae rhamnoides L.) is a yellow-to-orange berry fruit, which grows in low humid, alluvial gravel and wet landslips belonging to the Elaeagnaceae family. In Romania, sea buckthorn is widespread all over the fields, hills, and mountains [1]. Considering the high amounts of natural antioxidants including ascorbic acid, tocopherols, carotenoids, flavonoids, as well as health beneficial fatty acids, sea buckthorn is a prophylactic and a healing plant. Therefore, sea buckthorn is recognized to be used as alternative method in supporting the treatment or prevention of some illnesses such as: gastrointestinal disorders, obesity, diabetes, nervous system, and cardiovascular diseases [2].

The antioxidant activity of the specific bioactive compounds from sea buckthorn is involved in the improving of eyesight, hair, and skin quality, as well as it has antiproliferative effects for colon, liver, and breast cancer cells and leukemia cells [3]. In general, sea buckthorn berries are used as extracts, having many beneficial properties. For examples, besides antioxidative, anticancer, anti-inflammatory, anti-bacterial, and tissue protective [4]; recently, it has been demonstrated that the consumption of extract from sea-buckthorn berries leads to increase in number of selected types of stem cells (progenitor, endothelial, and lymphocytoid mesenchymal stem cells) in circulating blood [5]. However, the taste of sea buckthorn berries is not attractive for the consumers, being sour and astringent, due to the lack of natural sugars. Therefore, one of the proposed methods to improve the sensorial properties is to process the berries into jams and marmalade. Moreover, the 
short shelf life of fresh fruits and fruit off-season availability could be adversely affected if processing is not possible. Preserved food plays an important role modern consumers' life. Marmalade is a very popular jellified product based on sugar or sweeteners with special nutritional qualities. It is well known that marmalade is a mixture, brought to a suitable gelled consistency, of water, sugars and fruit pulp, fruit purée, fruit juice, fruit peel or aqueous extract of fruit or any combination thereof, in every case obtained from citrus fruit, such that the quantity of citrus fruit used for every $1000 \mathrm{~g}$ of the finished product is not less than $200 \mathrm{~g}$, of which not less than $75 \mathrm{~g}$ is obtained from the endocarp" [6]. The long stability of the marmalades could be achieved through a combination of thermal processing, control of water activity, and $\mathrm{pH}$. The nutritional and biological properties of sea buckthorn need to be sustained by the addition of healthy sugar, such as whole cane or stevia sugar. Whole cane sugar does not involve the refining process and contains the natural molasses and the natural nutrients of sugar cane [7]. It mainly consists of fructose, glucose, and sucrose, and other minor nutrients which contribute to the biological and nutritional value such as: phenolics, proteins, minerals, and natural asparagines [8]. Stevia is an alternative sugar extracted from the leaves of Stevia rebaudiana plant. Considered as a non-nutritive natural sweetener, stevia represents a safe sugar substitute that does not affect human health [9], because it is non-metabolizable (non-caloric), non-fermentable, and does not cause dental caries and diabetes.

Therefore, the aim objective of this study was to contribute to the development of two types of sea buckthorn berries-based marmalades. Two variants of novel marmalades were obtained and characterized, based on phytochemicals, microbiological profile, and their overall acceptability. The results highlighted the potential of using sea buckthorn as a rich source of bioactives for jellified or sugar-based product development.

\section{Results}

\subsection{Phytochemical Profile of the Samples}

The phytochemical analyses were determined for the blank sample represented by the sea buckthorn pulp (C) and for the processed samples in both variants (sea buckthorn marmalade with whole cane sugar ( $\operatorname{coded}$ as $C_{z}$ ) and with stevia sugar (coded as $C_{s}$ ), respectively). The results are shown in Table 1. The sea buckthorn pulp (C) showed a carotenoid content of $1.02 \pm 0.052 \mathrm{mg} / \mathrm{g}$ dry weight (DW), with a lycopene of $1.09 \pm 0.063 \mathrm{mg} / \mathrm{g}$ DW. Processing into marmalades lead to a reduction of carotenoids to $0.97 \pm 0.03 \mathrm{mg} / \mathrm{g}$ DW in $C_{z}$ and an increase in $C_{s}$ to $2.69 \pm 0.14 \mathrm{mg} / \mathrm{g} D W$. The significant differences in carotenoids content in the two samples are due to the combined effect of sugars and thermal treatment. Therefore, it has been suggested that carotenoids need to be released from plant cell, solubilized into the lipid phase, and incorporated into mixed micelles with certain hydrolysates of lipids before absorption [10]. In addition to thermal treatment, an interaction between carotenoids and polysaccharides is needed to improve carotenoid bioaccesibility during digestion and absorption. Several studies reported that the network formed by de-esterified pectin molecules held together by hydrogen bonding and hydrophobic interactions induced by ultrasound treatment resulted in gel-like properties within the tomato pulp that inhibited lycopene digestion [11]. The results are highly corelated with the texture profile of sea buckthorn marmalades, with a denser and tighter gel network for $C_{z}$, which caused a significant higher firmness value. 
Table 1. Phytochemical properties of the marmalade samples.

\begin{tabular}{|c|c|c|c|c|c|}
\hline Code & $\begin{array}{c}\beta-\text { Caroten, } \mathrm{mg} / \mathrm{g} \\
\text { DW }\end{array}$ & $\begin{array}{c}\text { Lycopene, mg/g } \\
\text { DW }\end{array}$ & TFC, mg EC/g DW & $\begin{array}{c}\text { TPC, mg EAG/g } \\
\text { DW }\end{array}$ & $\begin{array}{l}\text { ABTS, } \mu \text { Mol } \\
\text { Trolox/g DW }\end{array}$ \\
\hline $\mathrm{C}$ & $1.02 \pm 0.05^{\mathrm{a}}$ & $1.09 \pm 0.06^{\mathrm{a}}$ & $31.14 \pm 3.75^{\mathrm{a}}$ & $24.30 \pm 0.37^{a}$ & $121.12 \pm 0.01^{\mathrm{a}}$ \\
\hline $\mathrm{C}_{\mathrm{z} 0}$ & $0.91 \pm 0.03^{\mathrm{a}}$ & $0.13 \pm 0.02^{\mathrm{a}}$ & $55.99 \pm 3.79^{a}$ & $59.41 \pm 1.13^{\mathrm{a}}$ & $45.12 \pm 0.001^{\mathrm{a}}$ \\
\hline $\mathrm{C}_{\mathrm{z} 7}$ & $0.52 \pm 0.005^{\mathrm{a}}$ & $0.12 \pm 0.002^{\mathrm{a}}$ & $51.25 \pm 0.79^{a}$ & $57.07 \pm 2.99^{a}$ & $46.34 \pm 0.01^{\mathrm{a}}$ \\
\hline $\mathrm{C}_{\mathrm{z} 14}$ & $0.43 \pm 0.002^{\mathrm{a}}$ & $0.09 \pm 0.004^{\mathrm{a}}$ & $33.98 \pm 1.94^{\mathrm{a}}$ & $54.34 \pm 3.13^{a}$ & $43.03 \pm 0.01^{a}$ \\
\hline $\mathrm{C}_{\mathrm{z} 21}$ & $0.35 \pm 0.01^{\mathrm{a}}$ & $0.07 \pm 0.001^{\mathrm{a}}$ & $30.77 \pm 0.09^{a}$ & $51.67 \pm 2.90^{\mathrm{a}}$ & $42.08 \pm 0.02^{\mathrm{a}}$ \\
\hline $\mathrm{C}_{\mathrm{s} 0}$ & $2.69 \pm 0.14^{\mathrm{a}}$ & $1.20 \pm 0.013^{a}$ & $67.35 \pm 2.11^{\mathrm{a}}$ & $72.44 \pm 2.31^{\mathrm{a}}$ & $118.07 \pm 0.01^{\mathrm{a}}$ \\
\hline $\mathrm{C}_{\mathrm{s} 7}$ & $2.28 \pm 0.04^{\mathrm{a}}$ & $0.54 \pm 0.07^{\mathrm{a}}$ & $63.60 \pm 1.67^{\mathrm{a}}$ & $66.55 \pm 0.77^{\mathrm{a}}$ & $114.04 \pm 0.03^{\mathrm{a}}$ \\
\hline $\mathrm{C}_{\mathrm{s} 14}$ & $2.13 \pm 0.05^{\mathrm{a}}$ & $0.31 \pm 0.015^{\mathrm{a}}$ & $41.70 \pm 1.94^{\mathrm{a}}$ & $61.14 \pm 0.78^{a}$ & $109.10 \pm 0.01^{\mathrm{a}}$ \\
\hline $\mathrm{C}_{\mathrm{s} 21}$ & $2.03 \pm 0.01^{\mathrm{a}}$ & $0.27 \pm 0.001^{\mathrm{a}}$ & $31.02 \pm 1.67^{\mathrm{a}}$ & $59.64 \pm 3.09^{a}$ & $106.02 \pm 0.01^{\mathrm{a}}$ \\
\hline
\end{tabular}

TPC, total phenolic content; TFC, total flavonoid content; C—sea buckthorn blank samples; $C_{z}$-sea buckthorn marmalade with whole cane sugar samples; $C_{s}$ - sea buckthorn marmalade with stevia sugar samples, $0,7,14,21$ - the days of the analysis. Values are represented as mean \pm standard errors. The same superscript letter $\left({ }^{a}\right)$ means no significant differences $(p=0.05)$ between the parameters for the same column.

Therefore, it can be appreciated that the carotenoids content in terms of total carotenoids, $\beta$-carotene, and lycopene in $C_{z}$ is lower due to the complex interaction of these bioactives with pectin and other macromolecular polysaccharides in the heat-treated samples, leading to significant differences in apparent viscosity of the samples. Additionally, it is well known that stevia is a sugar substitute with a considerable thermal (up to $80^{\circ} \mathrm{C}$ ) and $\mathrm{pH}$ (2-10) stability [12]. A protective effect of the steviol glycosides on carotenoids also could be suggested.

The total polyphenols content (TPC) showed values of $24.30 \pm 0.37 \mathrm{mg}$ GAE $/ \mathrm{g}$ DW in C, $59.41 \pm 1.13 \mathrm{mg} \mathrm{GAE} / \mathrm{g}$ DW in $\mathrm{C}_{\mathrm{z}}$ and $72.44 \pm 2.31 \mathrm{mg} \mathrm{GAE} / \mathrm{g} \mathrm{DW}$ in $\mathrm{C}_{\mathrm{s}}$. Mendelová et al. [13], as well as Ivanišová et al. [14], reported for different varieties of sea buckthorn juice values of TPC in the range of $13.03-25.35 \mathrm{~g} \mathrm{GAE} / \mathrm{dm}^{-3} \mathrm{DW}$. The values from the literature are lower compared to the presented one, which is expected, due to the benefits of the thermal treatment, which made the releasing of the bioactive compounds possible.

Total flavonoids (TFC) values were $31.14 \pm 3.75 \mathrm{mg} Q \mathrm{QE} / \mathrm{g}$ DW in C and $55.99 \pm 3.79 \mathrm{mg}$ $\mathrm{QE} / \mathrm{g}$ DW in $\mathrm{C}_{\mathrm{Z}}$ and $67.35 \pm 2.11 \mathrm{mg} \mathrm{QE} / \mathrm{g} \mathrm{DW}$ in $\mathrm{C}_{\mathrm{s}}$, respectively.

The phytochemicals profile led to higher antioxidant activity in $C$ of $121 \pm 0.01 \mu \mathrm{Mol}$ Trolox/g DW, whereas the marmalades samples showed values of $45.12 \pm 0.001 \mu \mathrm{Mol}$ Trolox/g DW in $\mathrm{C}_{\mathrm{z}}$ and $118.07 \pm 0.01 \mu \mathrm{Mol}$ Trolox/g DW in $\mathrm{C}_{\mathrm{s}}$. The lower apparent viscosity of $\mathrm{C}_{\mathrm{s}}$ sample led to a higher value for hydrophilic bioactives and antioxidant activity.

\subsection{Phytochemicals Stability during Accelerated Storage}

Both samples were packed into glass jars and stored to room temperature $\left(21 \pm 2{ }^{\circ} \mathrm{C}\right)$ for 21 days to evaluate the phytochemicals stability during storage. The large loss of nutrients and bioactive [15] ingredients induced by the storage of the $C_{z}$ samples can affect the technological characteristics of the product, leading to the selection of appropriate processing parameters and optimization of the proper ingredients in the product.

The carotenoids decreasing (from $0.97 \pm 0.04$ to $0.35 \pm 0.01 \mathrm{mg} / \mathrm{g} \mathrm{DW}$ ) after 21 days of storage for the samples with whole sugar addition could be generated by the acid formation, degradation of polysaccharides, or oxidation of reducing sugars. These results are in accordance with the findings of Kanwal, Randhawa, \& Iqbal [16]. In $\mathrm{C}_{\mathrm{s}}$, the heatstability up to $200^{\circ} \mathrm{C}$, acid-stable, and non-fermentable characteristics of stevia sugar [17] induced the slightly decreased trend of carotenoids during storage. It could be seen that lycopene was severely affected by the storage. Similar to Li et al. [18] which determined a significant loss of lycopene in tomato hot pot sauce after 30 days of storage at 25 and $37^{\circ} \mathrm{C}$, for sea buckthorn marmalades, the storage decreased the lycopene content with $50 \%$ for the $\mathrm{C}_{\mathrm{Z}}$ samples and with almost $77 \%$ for $\mathrm{C}_{\mathrm{s}}$. Specific water activity $(0.86-0.95 \%)$ is an important factor which could influence the lycopene degradation alongside to temperature, light, 
oxygen. Therefore, the decrease in lycopene content could be explained by the reversion from cis to trans isomers which is generated by the unstable state of cis isomer [19].

For all samples, the initial total polyphenol content slightly decreased by the end of storage in the range of $13-17 \%$. Thereafter, the downward trend continues by the end of storage for the TFC with significant values of $45 \%$ for $C_{z}$ sample and $54 \%$ for $C_{s}$. However, the TFC and the antioxidant activity values are higher than the results reported for various berries jams reported by [20]. The marmalades with Stevia sugar addition preserved better the bioactive compounds during storage, with a decrease in antioxidant values from $118 \pm 0.01$ to $106 \pm 0.01 \mu \mathrm{Mol}$ Trolox/g DW.

\subsection{Color Parameters}

Table 2 shows the variation of color parameters. A slightly decrease in $\mathrm{L}^{*}$ and $\mathrm{b}^{*}$ values can be observed with increasing storage time for the $C_{s}$ marmalade, probably due to carotenoids degradation. Similar findings were reported by Lele et al. [21] for sea buckthorn and quince juice. Significant decrease of almost $88 \%$ in lightness and yellow color can be noticed for the $C_{z}$ sample, that could be assigned to the whole cane sugar addition, which is dark brown.

Table 2. Color parameters of marmalades.

\begin{tabular}{ccccccc}
\hline Code & $\mathbf{L}^{*}$ & $\mathbf{a}^{*}$ & $\mathbf{b}^{*}$ & $\Delta \mathbf{E}$ & $\mathbf{C}^{*}$ & $\mathbf{h}^{*}$ \\
\hline $\mathrm{C}$ & $50.35 \pm 0.05^{\mathrm{a}}$ & $12.94 \pm 0.1^{\mathrm{a}}$ & $36.41 \pm 0.5^{\mathrm{a}}$ & - & $38.63 \pm 0.3^{\mathrm{a}}$ & $20.33 \pm 0.2^{\mathrm{a}}$ \\
$\mathrm{C}_{\mathrm{z} 0}$ & $20.5 \pm 0.15^{\mathrm{a}}$ & $7.27 \pm 0.01^{\mathrm{a}}$ & $3.7 \pm 0.05^{\mathrm{a}}$ & $44.65 \pm 0.3^{\mathrm{a}}$ & $8.15 \pm 0.1^{\mathrm{a}}$ & $112.78 \pm 0.8^{\mathrm{a}}$ \\
$\mathrm{C}_{\mathrm{z} 7}$ & $20.44 \pm 0.25^{\mathrm{a}}$ & $7.13 \pm 0.03^{\mathrm{a}}$ & $3.64 \pm 0.1^{\mathrm{a}}$ & $44.74 \pm 0.5^{\mathrm{a}}$ & $8.00 \pm 0.15^{\mathrm{a}}$ & $112.34 \pm 0.9^{\mathrm{a}}$ \\
$\mathrm{C}_{\mathrm{z} 14}$ & $20.34 \pm 0.1^{\mathrm{a}}$ & $7.41 \pm 0.05^{\mathrm{a}}$ & $4.62 \pm 0.05^{\mathrm{a}}$ & $44.07 \pm 0.3^{\mathrm{a}}$ & $8.72 \pm 0.2^{\mathrm{a}}$ & $92.4 \pm 0.6^{\mathrm{a}}$ \\
$\mathrm{C}_{\mathrm{z} 21}$ & $20.27 \pm 0.15^{\mathrm{a}}$ & $7.22 \pm 0.1^{\mathrm{a}}$ & $4.21 \pm 0.1^{\mathrm{a}}$ & $44.44 \pm 0.4^{\mathrm{a}}$ & $8.35 \pm 0.05^{\mathrm{a}}$ & $98.37 \pm 0.4^{\mathrm{a}}$ \\
$\mathrm{C}_{\mathrm{s} 0}$ & $40.01 \pm 0.15^{\mathrm{a}}$ & $11.09 \pm 0.03^{\mathrm{a}}$ & $31.95 \pm 0.2^{\mathrm{a}}$ & $11.41 \pm 0.15^{\mathrm{a}}$ & $33.81 \pm 0.3^{\mathrm{a}}$ & $19.87 \pm 0.6^{\mathrm{a}}$ \\
$\mathrm{C}_{\mathrm{S} 7}$ & $40.13 \pm 0.05^{\mathrm{a}}$ & $11.01 \pm 0.2^{\mathrm{a}}$ & $31.06 \pm 0.1^{\mathrm{a}}$ & $11.7 \pm 0.1^{\mathrm{a}}$ & $32.95 \pm 0.2^{\mathrm{a}}$ & $20.3 \pm 0.8^{\mathrm{a}}$ \\
$\mathrm{C}_{\mathrm{s} 14}$ & $41.31 \pm 0.03^{\mathrm{a}}$ & $11.17 \pm 0.3^{\mathrm{a}}$ & $34.32 \pm 0.15^{\mathrm{a}}$ & $9.47 \pm 0.2^{\mathrm{a}}$ & $36.09 \pm 0.5^{\mathrm{a}}$ & $18.63 \pm 0.2^{\mathrm{a}}$ \\
$\mathrm{C}_{\mathrm{s} 21}$ & $41.35 \pm 0.2^{\mathrm{a}}$ & $11.16 \pm 0.2^{\mathrm{a}}$ & $36.35 \pm 0.2^{\mathrm{a}}$ & $9.34 \pm 0.15^{\mathrm{a}}$ & $36.4 \pm 0.5^{\mathrm{a}}$ & $17.42 \pm 0.1^{\mathrm{a}}$ \\
\hline
\end{tabular}

$\mathrm{L}^{*}$ (lightness/darkness), $\mathrm{a}^{*}$ (red/green) and $\mathrm{b}^{*}$ (yellow/blue), $\Delta \mathrm{E}$-total color difference, $\mathrm{h}^{*}$ —hue angle, $\mathrm{C}^{*}$ —chroma, color intensity. Values are represented as mean \pm standard errors. Means in a row bearing the same superscript letters do not differ significantly.

The addition of steviol glycosides lead the marmalade samples to more yellow (increase in the positive values of the $b^{*}$ parameter), and less red (positive value of the $a^{*}$ parameter), when compared to the samples with whole sugar cane. Similar findings were reported by [22] for low sugar apple preserves. It seems that stevia sugar addition and thermal treatment at $102^{\circ} \mathrm{C}$ do not affect the color characteristics of the marmalade, sustained by the $\Delta \mathrm{E}(11.41 \pm 0.15), \mathrm{C}^{*}(33.81 \pm 0.3)$ and $\mathrm{h}^{*}(19.87 \pm 0.6)$ values for the $\mathrm{C}_{\mathrm{s}}$ sample, whereas a storage period of 21 days led to a slight decrease of these values. The significant decrease of chroma values of almost $80 \%$ correlated with the six-times higher increased values of hue are related to the whole sugar cane addition and its caramelization capacity during the thermal treatment for the $C_{z}$ sample.

In summary, the color of sea buckthorn marmalade depends on the sugar and steviol glycosides content, as well as the thermal treatment impact. Addition of whole cane sugar induced darkness to the $C_{z}$ marmalade samples, whereas samples using stevia sugar were brighter.

\subsection{Texture Profile of Sea Buckthorn Marmalades}

The results of the texture analysis are shown in Table 3. 
Table 3. Texture parameters values for marmalade samples.

\begin{tabular}{ccc}
\hline Texture Parameter & $\mathbf{C}_{\mathbf{s}}$ & $\mathbf{C}_{\mathbf{z}}$ \\
\hline Firmness, N & $1.25 \pm 0.03^{\mathrm{b}}$ & $4.31 \pm 0.76^{\mathrm{b}}$ \\
Adhesiveness, mJ & $1.98 \pm 0.2^{\mathrm{b}}$ & $3.56 \pm 0.96^{\mathrm{b}}$ \\
Cohesiveness & $0.6 \pm 0.05^{\mathrm{b}}$ & $0.28 \pm 0.02^{\mathrm{b}}$ \\
Springiness, $\mathrm{mm}$ & $8.1 \pm 0.82^{\mathrm{a}}$ & $8.84 \pm 0.68^{\mathrm{a}}$ \\
\hline
\end{tabular}

The values are presented as means \pm standard deviation. Different superscript letters ( $a$ and $b$ ) mean a significant difference at $(p<0.05)$ among different parameters for the same column.

Firmness is defined as the maximum force at the first compression. It is an expression of the gel resistance against deformation. In $C_{z}$ sample, the added sugar reacted with pectin from sea buckthorn, leading to a denser and tighter gel network [23], which determined a 3.4-times higher firmness value, compared to the $C_{S}$ sample. Similar firmness values were reported for shaped jelly marmalade with cranberry concentrate [24]. Sugar substitution determined lower values of adhesiveness, which is defined as the negative work between the two cycles. A similar behavior was observed by [25] for jam, in which a part of the sucrose was replaced with steviol glycoside. Cohesiveness is how well the product withstands a second deformation relative to its resistance under the first deformation [26]. The results show the highest cohesiveness value (0.6) for $\mathrm{C}_{\mathrm{S}}$ sample. Springiness is measure of how well the sample recovers the deformation after the first compression cycle. For the sea buckthorn marmalade samples, slight differences can be noticed for this parameter. The instrumental texture analysis shows high correlation with sensorial analysis.

\subsection{Microbial Evaluation of the Stored Marmalades}

The microbiological analyses revealed that the sea buckthorn marmalades were microbiologically satisfactory during the storage period (Tables 4 and 5).

Table 4. Yeasts and molds enumeration during storage, CFU/g.

\begin{tabular}{ccccc}
\hline \multirow{2}{*}{ Sample } & \multicolumn{4}{c}{ Storage Period, Days } \\
\cline { 2 - 5 } & $\mathbf{0}$ & $\mathbf{7}$ & $\mathbf{1 4}$ & $\mathbf{2 1}$ \\
\hline $\mathrm{C}_{\mathrm{S}}$ & $<100$ & $<100$ & $<100$ & $<100$ \\
$\mathrm{C}_{\mathrm{z}}$ & $<100$ & $<100$ & $<100$ & $<100$ \\
\hline
\end{tabular}

Table 5. Enterobacteriaceae enumeration during storage, $\mathrm{CFU} / \mathrm{g}$.

\begin{tabular}{ccccc}
\hline \multirow{2}{*}{ Sample } & \multicolumn{5}{c}{ Storage Period, Days } \\
\cline { 2 - 5 } & $\mathbf{0}$ & $\mathbf{7}$ & $\mathbf{1 4}$ & $\mathbf{2 1}$ \\
\hline $\mathrm{C}_{\mathrm{s}}$ & $<5$ & $<5$ & $<5$ & $<5$ \\
$\mathrm{C}_{\mathrm{z}}$ & $<5$ & $<5$ & $<5$ & $<5$ \\
\hline
\end{tabular}

The results were in accordance with Selvamuthukumaran \& Khanum [27], who obtained a sea buckthorn marmalade rich in antioxidants, with non-detectable microbial population during 8 months of storage at room temperature.

\subsection{Sensorial Evaluation of the Marmalade Samples}

The general aspect of the marmalade with whole cane sugar $\left(C_{z}\right)$ gained the highest value of 4.67 , while the marmalade with stevia sugar $\left(C_{s}\right)$ registered a 3.77 score. The most preferred sample was $C_{z}$, which registered for all the attributes the highest scores excepting the color, as it can be observed from the Figure 1. 


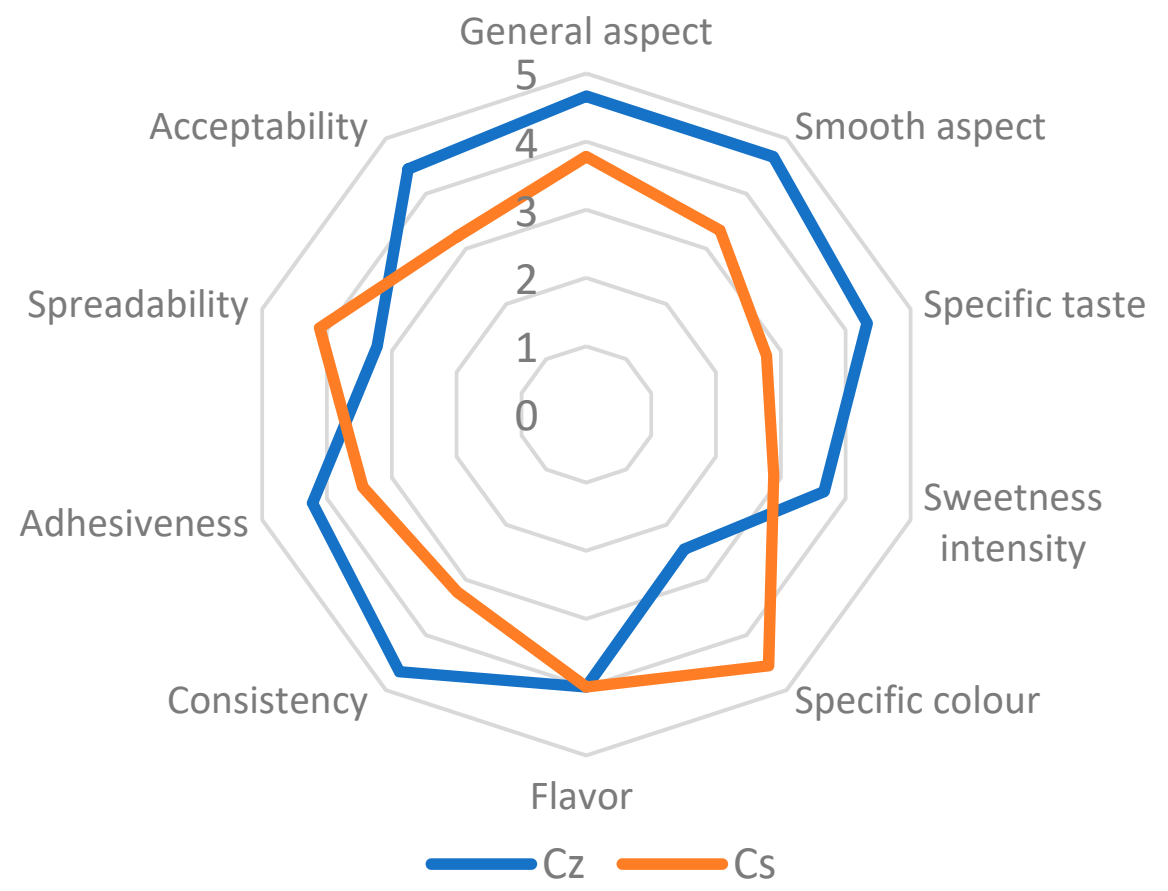

Figure 1. Sensorial analysis of sea buckthorn marmalades.

The $C_{s}$ marmalade color was more appreciated with 4.56 points than the $C_{z}$ sample with 2.44 points. This fact could be explained by the whole sugar cane directly influence on the $\mathrm{C}_{\mathrm{z}}$ sample color. The panelists appreciated the taste and the textural characteristics represented by the consistency and adhesiveness of the marmalade with whole sugar cane. Similar results were obtained by Emelike \& Akusu [28] for some marmalades and jams from tropical fruits and by Selvamuthukumaran \& Khanum [27] for sea buckthorn jam. There were significant differences between the marmalade types of color, texture, spreadability, and taste. It is a notable the fact that stevia sugar has influenced the specific taste of sea buckthorn marmalade. No significant differences $(p>0.05)$ were determined between the sensorial attributes of the marmalade samples.

\section{Materials and Methods}

\subsection{Chemicals}

Ethanol, Folin-Ciocalteu's reagent, sodium carbonate, ABTS (2,2-azino-bis (3-ethylbenzothiazoline-6-sulfonic acid) diammonium salt), quercetin, aluminum chloride, potassium chloride, sodium acetate, and petroleum ether were purchased from Sigma Aldrich (MilliporeSigma, Steinheim, Germany).

\subsection{Plant Material}

Freeze ecological sea buckthorn were purchased from a local supermarket from Galati, Romania in November 2020. The sea buckthorn was thawed to the room temperature, then sorted and washed under cold water jet.

\subsection{Marmalade Making}

Two types of marmalades were obtained based on $1000 \mathrm{~g}$ of sea buckthorn berries and $500 \mathrm{~g}$ of whole cane sugar (SanoVita, Valcea, Romania) or the correspondent of the sweetening power of $62.5 \mathrm{~g}$ of stevia sugar (Nutrivita, Ilfov, Romania) as well as $0.5 \%$ apple pectin (Pektin, Nature Cookta, Budapest, Hungary). The fruits were crushed in a blender for $3 \mathrm{~min}$ at $1000 \mathrm{rpm}$ with a Philips HR2100/40 blender, EC (European Community). Furthermore, the obtained puree was blended with apple pectin, whole cane sugar, or stevia sugar for $7 \mathrm{~min}$ at the same speed. In between each addition, the substance was stirred continuously. The mixes were heated in a non-stick electric pot (Multicooker Philips 
HD3037/70, Hamburg, Germany) at $102{ }^{\circ} \mathrm{C}$ for one hour in the sugar case and half an hour for stevia. The final consistency of the marmalade was tested by the cold test, using a cold plate to determine the extent of the gelation. The marmalade was packed into glass jars and stored at room temperature $\left(21 \pm 2{ }^{\circ} \mathrm{C}\right)$.

\subsection{Phytochemical Profile}

\subsubsection{Extraction of Bioactive Compounds}

For total polyphenolic and flavonoidic content, the sea buckthorn marmalades ( $1 \mathrm{~g})$ were homogenized with $8 \mathrm{~mL}$ ethanol (70\%) and stirred using an orbital shaker at room temperature for $24 \mathrm{~h}$ to extract the biological active compounds. The obtained extract was centrifuged at a speed of $5000 \times g$ for $30 \mathrm{~min}$. For the phytochemical profile were used three samples for each marmalade.

\subsubsection{Determination of Total Phenolic and Total Flavonoid Content}

The total polyphenolic content (TPC) and flavonoids content (TFC) were determined as described by [29].

\subsubsection{Antioxidant Activity by ABTS Assay}

The ABTS+ radical's method was employed as described by Xu, Chen, \& Guo [30]. In brief, ABTS radical cation (ABTS-+) was produced by reacting equal volumes of $7 \mathrm{mM}$ ABTS stock solution with $2.45 \mathrm{mM} \mathrm{K}_{2} \mathrm{~S}_{2} \mathrm{O}_{8}$ and allowing the mixture to stand in dark for $16 \mathrm{~h}$ before use. Further, aliquots of $1 \mathrm{~mL}$ ABTS + solution was diluted with $35 \mathrm{~mL}$ methanol to get absorbance of $1.12 \pm 0.02$ at $734 \mathrm{~nm}$. A volume of $2.85 \mathrm{~mL}$ of the ABTS.+ solution and $0.15 \mathrm{~mL}$ of the sample could react for $2 \mathrm{~h}$ in a dark room before its absorbance at $734 \mathrm{~nm}$ was measured. The ABTS + antioxidant activity of the samples was expressed as $\mathrm{mM}$ Trolox equivalents/g DW based on the calibration curve.

\subsubsection{Extraction of Carotenoids from Sea Buckthorn Marmalades}

An amount of $2 \mathrm{~g}$ of sea buckthorn marmalade samples was homogenized with $10 \mathrm{~mL}$ of petroleum ether. Then, the extraction was further performed by ultrasonication for 30 min (MRC Scientific Instruments, Essex, United Kingdom). The ultrasonic bath is equipped with a digital control system of sonication time, temperature, and frequency. The extraction was performed at a constant frequency of $40 \mathrm{kHz}$ and power of $100 \mathrm{~W}$. The resulting supernatant was collected and centrifuged at $9000 \times g$, at $10{ }^{\circ} \mathrm{C}$ for $10 \mathrm{~min}$.

\subsubsection{Carotenoids Content}

Carotenoids content, in terms of total carotenoids, $\beta$-carotene and lycopene were determined by spectrophotometric method. The absorbance was measured at $470 \mathrm{~nm}, 450 \mathrm{~nm}$, and $503 \mathrm{~nm}$. The amount of carotenoids was calculated according to the equation [31]

$$
\text { Carotenoids }(\mathrm{mg} / \mathrm{g})=\mathrm{A} \cdot \mathrm{M}_{\mathrm{W}} \cdot \mathrm{D}_{\mathrm{f}} /\left(\mathrm{M}_{\mathrm{a}} \cdot \mathrm{L}\right)
$$

where A-absorbance of the petroleum ether phase at corresponding wavelength; $\mathrm{Mw}$ - molecular weight, $\mathrm{D}_{\mathrm{f}}$ - sample dilution rate, $\mathrm{M}_{\mathrm{a}}$-molar absorptivity $\left(2500 \mathrm{~L} \mathrm{~mol}^{-1}\right.$ $\mathrm{cm}^{-1}, 2590 \mathrm{~L} \mathrm{~mol}^{-1} \mathrm{~cm}^{-1}$ and $3450 \mathrm{~L} \mathrm{~mol}^{-1} \mathrm{~cm}^{-1}$, respectively), and L-cell diameter of the spectrophotometer $(1 \mathrm{~cm})$.

\subsection{Color}

The color of the marmalades samples was measured using a MINOLTA Chroma Meter CR-410 (Konica Minolta, Osaka, Japan) fitted with a granular accessory, after standardization with a white calibration plate according to the equipment specifications. The 
determined parameters were $\mathrm{L}^{*}$ (lightness/darkness), $\mathrm{a}^{*}$ (red/green) and $\mathrm{b}^{*}$ (yellow/blue). The total color difference $(\Delta E)$ between samples was calculated according to Equation (2)

$$
\Delta E=\sqrt{\left(\mathrm{L}_{0}^{*}-\mathrm{L}^{*}\right)^{2}+\left(\mathrm{a}_{0}^{*}-\mathrm{a}^{*}\right)^{2}+\left(\mathrm{b}_{0}^{*}-\mathrm{b}^{*}\right)^{2}}
$$

Subscript 0 refers to the color of the fresh sample. The hue angle $\left(\mathrm{h}^{*}\right)$, visual color appearance, and chroma $\left(C^{*}\right)$, color intensity, were calculated according to Equations (3) and (4), using the formula

$$
\begin{aligned}
& \mathrm{C}^{*}=\sqrt{\mathrm{a}^{* 2}+\mathrm{b}^{* 2}} \\
& \mathrm{~h}^{*}=\tan ^{-1}\left(\frac{\mathrm{b}^{*}}{\mathrm{a}^{*}}\right)
\end{aligned}
$$

Three replicates were carried out for each sample.

\subsection{Texture}

Texture Profile Analysis (TPA) method, achieved with a CT3-1000 Texture Analyzer (Brookfield Ametek, Middleborough, MA, USA) was used to evaluate the textural properties of the samples. The hot samples were poured into cylindrical plastic containers, with $43 \mathrm{~mm}$ diameter and $40 \mathrm{~mm}$ high (the sample height was approximatively $30 \mathrm{~mm}$ ). After reaching the room temperature, the samples were introduced into a refrigerator and kept until the next day. Before testing, the samples were equilibrated at room temperature and subjected to a double penetration test (texture profile analysis-TPA), until the target distance of $10 \mathrm{~mm}$ was reached. For testing, a cylindrical acrylic probe, with $12.7 \mathrm{~mm}$ was used. Test speed was $1 \mathrm{~mm} / \mathrm{s}$, trigger load was $0.067 \mathrm{~N}$ and the lode cell was $1000 \mathrm{~g}$. TexturePro CT V1.5 software was used to register the force-deformation parameters and to calculate the textural parameters: firmness, adhesiveness, cohesiveness, and springiness. Four determinations for each sample were done.

\subsection{Microbial Shelf-Life Examination of Sea Buckthorn Marmalades}

To count the Enterobacteriaceae, yeasts and molds, the standards ISO 21528-2:2017 [32] and ISO 21527-2:2008 [33] were used.

\subsection{Sensorial Evaluation}

The sensorial evaluation of the marmalades was conducted as described by Emelike \& Akusu [28] using 10 panelists, aged 27-44 years, selected from the university community, whose experience in sensory evaluation in this type of product were acknowledged.

The panelists were trained before the final sensorial evaluation. Training happened over a period of one months with one session per week. Each panelist tested a number of no more than four samples for test with breaks included between tests. The aim of the training was to be familiarized with the marmalade attributes and to learn the specific terminology to describe the samples. The samples were stored at the room temperature and tested after a week from the production point, packaged in transparent packages and presented in a coded manner. The sensorial attributes of the samples were: general aspect, smooth aspect, specific taste, sweetness intensity, specific color, flavor, consistency, adhesiveness, spreadability, and acceptability. All the terms were defined to the panelists. The panelists were requested to observe and taste each sample as coded and grade them based on a five-point hedonic scale, where 1 represents the lowest grade and 5 the highest grade. After evaluating each sample, they rinse their mouth with potable water to hesitate the taste interference.

\subsection{Statistical Analysis}

The results referring to phytochemicals, texture, color, and sensorial parameters were statistically analyzed using a Minitab 19 software-Free Trial (Ottawa, ON, Canada) to identify significant differences. The Tukey's test with a 95\% confidence interval was applied. 


\section{Conclusions}

Attempts were made in this study to identify proper technological approaches for novel sea buckthorn sugar-based and sugar-free marmalades, based on phytochemicals, textural, color, sensorial, and microbiological evaluation of the final products. Two different types of sugars were used-whole cane sugar and stevia sugar, respectively-based on developing food for the consumption of low calories foods. Significantly different phytochemicals and color profiles were highlighted for the marmalades, with a higher content of carotenoids and polyphenols, and consequently a higher antioxidant activity in marmalade with Stevia sugar addition, due to the specific network formed. Lower phytochemical content was found in marmalade with whole cane sugar due to the complex interaction of bioactives with pectin and other macromolecular polysaccharides in the heat-treated samples, leading to significant differences in apparent viscosity. Both types of marmalades could be safely stored up to a period of 21 days at room temperature, with no significant decrease in color parameters. However, phytochemicals were found to decrease during accelerated storage test, with a highest value for lycopene. The textural profile analysis suggested that the sugar substitution with Stevia determined lower values of the firmness and adhesiveness parameters. Sensorial analysis showed significant differences between the taste and the color of the samples influenced by both types of added sugar.

Author Contributions: Conceptualization, N.S.; Methodology, O.-V.N.; Formal analysis, O.-V.N., C.A.B., D.-G.A. and M.C.; Resources, N.S.; Writing-original draft preparation, O.-V.N., D.-G.A. and N.S.; Writing-review and editing, N.S.; Visualization, N.S.; Supervision, N.S.; Project administration, N.S. All authors have read and agreed to the published version of the manuscript.

Funding: This research received no external funding.

Institutional Review Board Statement: Not applicable.

Informed Consent Statement: Not applicable.

Acknowledgments: The Integrated Center for Research, Expertise and Technological Transfer in Food Industry is acknowledged for providing technical support.

Conflicts of Interest: The authors declare no conflict of interest.

Sample Availability: Samples of the compounds are available from the authors.

\section{References}

1. Ciesarová, Z.; Murkovic, M.; Cejpek, K.; Kreps, F.; Tobolková, B.; Koplík, R.E.; Kukurová, K.; Daško, L’; Panovská, Z.; Revenco, D.; et al. Why is sea buckthorn (Hippophae rhamnoides L.) so exceptional? A review. Food Res. Int. 2020, 133, 109170. [CrossRef] [PubMed]

2. Bal, L.M.; Meda, V.; Naik, S.; Satya, S. Sea buckthorn berries: A potential source of valuable nutrients for nutraceuticals and cosmoceuticals. Food Res. Int. 2011, 44, 1718-1727. [CrossRef]

3. Guo, R.; Guo, X.; Li, T.; Fu, X.; Liu, R.H. Comparative assessment of phytochemical profiles, antioxidant and antiproliferative activities of Sea buckthorn (Hippophaë rhamnoides L.) berries. Food Chem. 2017, 221, 997-1003. [CrossRef] [PubMed]

4. Wang, K.; Xu, Z.; Liao, X. Bioactive compounds, health benefits and functional food products of sea buckthorn: A review. Crit. Rev. Food Sci. Nutr 2021, 1-22. [CrossRef]

5. Drapeau, C.; Benson, K.F.; Jensen, G.S. Rapid and selective mobilization of specific stem cell types after consumption of a polyphenol-rich extract from sea buckthorn berries (Hippophae) in healthy human subjects. Clin. Interv. Aging 2019, 14, 253-263. [CrossRef]

6. Wolf, B. Confectionery and Sugar-Based Foods. Ref. Mod. Food Sci. 2016, 1-4. [CrossRef]

7. Della Maggiore Orlandi, R.D.M.; Verruma-Bernardi, M.R.; Sartorio, S.D.; Mendes Ribeiro Borges, M.T. Physicochemical and Sensory Quality of Brown Sugar: Variables of Processing Study. J. Agric. Sci. 2017, 9, 115-121. [CrossRef]

8. Ducat, G.; Felsner, M.L.; Da Costa Neto, P.R.; Quinaia, S.P. Development and in house validation of a new thermogravimetric method for water content analysis in soft brown sugar. Food Chem. 2015, 177, 158-164. [CrossRef] [PubMed]

9. Gandhi, S.; Gata, Y.; Arya, S.; Kumara, V.; Panghala, A.; Kumar, A. Natural sweeteners: Health benefits of stevia. Foods Raw Mater. 2018, 6, 392-402. [CrossRef]

10. Mutsokoti, L.; Panozzo, A.; Tongonya, J.; Kebede, B.T.; Loey, A.; Hendrickx, M. Carotenoid stability and lipid oxidation during storage of low-fat carrot and tomato-based systems. LWT 2017, 80, 470-478. [CrossRef] 
11. Barba, F.J.; Mariutti, L.R.B.; Bragagnolo, N.; Mercadante, A.Z.; Barbosa-Cánovas, G.V.; Orlien, V. Bioaccessibility of bioactive compounds from fruits and vegetables after thermal and nonthermal processing. Trends Food Sci. Technol. 2017, 67, 195-206. [CrossRef]

12. Musa, A.; Miao, M.; Gasmalla, M.A.A.; Zhang, T.; Eibaid, A.; Aboshora, W.; Jiang, B. Stability of Stevioside and GlucosylStevioside under Acidic Conditions and its Degradation Products. J. Food Nutr. Res. 2014, 2, 198-203. [CrossRef]

13. Mendelová, A.; Mendel, L.; Czako, P.; Mareček, J. Evaluation of carotenoids, polyphenols content and antioxidant activity in the sea buckthorn fruit juice. Potravinarstvo 2016, 10, 59-64. [CrossRef]

14. Ivanišová, E.; Blašková, M.; Terentjeva, M.; Grygorieva, O.; Vergun, O.; Brindza, J.; Kačániová, M. Biological properties of sea buckthorn (Hippophae rhamnoides L.) derived products. Acta Sci. Pol. Technol. Aliment 2020, 19, 195-205. [CrossRef] [PubMed]

15. Tobal, T.M.; Rodrigues, L.V. Effect of storage on the bioactive compounds, nutritional composition and sensory acceptability of pitanga jams. Food Sci. Technol. 2019, 39. [CrossRef]

16. Kanwal, N.; Randhawa, M.A.; Iqbal, Z. Influence of processing methods and storage on physico-chemical and antioxidant properties of guava jam. Int. Food Res. J. 2017, 24, 2017-2027.

17. Kroyer, G. Stevioside and Stevia-sweetener in food: Application, stability and interaction with food ingredients. J. Verbr. Lebensm. 2010, 5, 225-229. [CrossRef]

18. Li, H.; Zhang, J.; Wang, Y.; Li, J.; Yang, Y.; Liu, X. The effects of storage conditions on lycopene content and color of tomato hot pot sauce. Int. J. Anal. Chem. 2018, 1273907. [CrossRef]

19. Urbonaviciene, D.; Bobinaite, R.; Bobinas, C.; Viskelis, P. Stability and isomerisation oflycopene in oil-based model system during accelerated shelf-life testing. In Proceedings of the 11th Baltic Conference on Food Science and Technology" Food Science and Technology in a Changing World" FOODBALT 2017, Jelgava, Latvia, 27-28 April 2017; Latvia University of Agriculture: Jelgava, Latvia, 2017; pp. 150-153. [CrossRef]

20. Diaconeasa, Z.; Iuhas, C.I.; Ayvaz, H.; Rugină, D.; Stanilă, A.; Dulf, F.; Bunea, A.; Socaci, S.A.; Socaciu, C.; Pintea, A. Phytochemical Characterization of Commercial Processed Blueberry, Blackberry, Blackcurrant, Cranberry, and Raspberry and Their Antioxidant Activity. Antioxidants 2019, 8, 540. [CrossRef] [PubMed]

21. Lele, V.; Monstaviciute, E.; Varinauskaite, I.; Peckaityte, G.; Paskeviciute, L.; Plytnikaite, M.; Tamosiunaite, V.; Pikunaite, M.; Ruzauskas, M.; Stankevicius, R.; et al. Sea Buckthorn (Hippophae rhamnoides L.) and Quince (Cydonia oblonga L.) Juices and Their By-Products as Ingredients Showing Antimicrobial and Antioxidant Properties for Chewing Candy: Nutraceutical Formulations. Hindawi J. Food Qual. 2018, 2018, 3474202. [CrossRef]

22. Pielak, M.; Czarniecka-Skubina, E.; Głuchowski, A. Effect of Sugar Substitution with Steviol Glycosides on Sensory Quality and Physicochemical Composition of Low-Sugar Apple Preserves. Foods 2020, 9, 293. [CrossRef]

23. Estaji, M.; Mohammadi-Moghaddam, T.; Gholizade-Eshan, L.; Firoozzare, A.; Hooshmand-Dalir, M.R. Physicochemical characteristics, sensory attributes, and antioxidant activity of marmalade prepared from black plum peel. Int. J. Food Prop. 2020, 23, 1979-1992. [CrossRef]

24. Alekseenko, E.V.; Ya Chernykh, V.; Bakumenko, O.E. Shaped jelly marmalade with cranberry concentrate. IOP Conf. Ser. Earth Environ. Sci. 2021, 640, 052007. [CrossRef]

25. Banas, A.; Korus, A.; Korus, J. Texture, Color, and Sensory Features of Low-Sugar Gooseberry Jams Enriched with Plant Ingredients with prohealth properties. J. Food Qual. 2018, 2018, 1646894. [CrossRef]

26. Wee, M.S.M.; Goh, A.T.; Stieger, M.; Forde, C.G. Correlation of instrumental texture properties from textural profile analysis (TPA) with eating behaviours and macronutrient composition for a wide range of solid foods. Food Funct. 2018, 10, 5301-5312. [CrossRef] [PubMed]

27. Selvamuthukumaran, M.; Khanum, F. Processing Sea Buckthorn Fruit for Antioxidant Rich Jam Development and Shelf Stability Assessment. Indian J. Tradit Knowl. 2014, 13, 335-346.

28. Emelike, N.J.T.; Akusu, O.M. Quality Attributes of Jams and Marmalades Produced from Some Selected Tropical Fruits. J. Food Proc. Technol. 2019, 10, 1-7. [CrossRef]

29. Bolea, C.; Turturică, M.; Stănciuc, N.; Vizireanu, C. Thermal degradation kinetics of bioactive compounds from black rice flour (Oryza sativa L.) extracts. J. Cereal Sci. 2016, 71, 160-166. [CrossRef]

30. Xu, Y.-B.; Chen, G.-L.; Guo, M.-Q. Antioxidant and Anti-Inflammatory Activities of the Crude Extracts of Moringa oleifera from Kenya and Their Correlations with Flavonoids. Antioxidants 2019, 9, 296. [CrossRef]

31. Souza, A.L.R.; Hidalgo-Chávez, D.W.; Pontes, S.M.; Gomes, F.S.; Cabral, L.M.C.; Tonon, L.V. Microencapsulation by spray drying of a lycopene-rich tomato concentrate: Characterization and stability. LWT Food Sci. Technol. 2018, 91, $286-292$.

32. ISO 21528-2:2017. Microbiology of the Food Chain-Horizontal Method for the Detection and Enumeration of Enterobacteriaceae-Part 2: Colony-Count Technique; ISO: Genève, Switzerland, 2017.

33. ISO 21527-2:2008. Microbiology of Food and Animal Feeding Stuffs—Horizontal Method for the Enumeration of Yeasts and Moulds—Part 2: Colony Count Technique in Products with Water Activity Less Than or Equal to 0.95; ISO: Genève, Switzerland, 2008. 